AMERICAN JOURNAL OF FOOD AND NUTRITION

Print: ISSN 2157-0167, Online: ISSN 2157-1317, doi:10.5251/ajfn.2011.1.1.7.13

(C) 2011, ScienceHu $\beta$, http://www.scihub.org/AJFN

\title{
Production and evaluation of millet-egg-soybean hull composite flour: A weaning food
}

\author{
${ }^{1,2}$ Ayo, J.A; ${ }^{1,3}$ Oluwalana I.B; ${ }^{1,4}$ Idowu M.A; ${ }^{1}$ Ikuomola D.S; ${ }^{2}$ Ayo, V.A; ${ }^{2}$ Umar.A and \\ ${ }^{2}$ Yusuf .E
}

\author{
Dept. of Food Science and Technology, \\ ${ }^{1}$ Joseph Ayo Babalola University, Ikeji-Arakekeji, PMB 5006, Ilesa. Osun State, Nigeria. \\ ${ }^{2}$ The Federal Polytechnic, PMB 0231, Bauchi. Nigeria. \\ ${ }^{3}$ Federal University of Technology, Akure Ondo State. Nigeria \\ ${ }^{4}$ University of Agriculture, Abeokuta. Ogun State. Nigeria
}

\begin{abstract}
Millet (Eleusine coracana), egg and soybean (Glycine max), were purchased in Gwallameji market, Bauchi, Nigeria. Millet grain was cleansed, washed, steeped (at room temperature for 2hours), washed, wet milled, sieved (muslin cloth), sediment, decanted, pressed, dried, pulverized, sieved to produce millet flour. Eggs (whole) were carefully broken, whisked, spray dried (Niro-Atomizer Spray Dryer at drying/product combination temperature of $150 / 75^{\circ} \mathrm{C}$ ) to produce egg powder. Soybeans were sorted, cleansed, washed, soaked (at room temperature for 12hours), dehulled (manually by robbing between palm), hull is dried (at $60^{\circ} \mathrm{C}$ for $3 \mathrm{hrs}$ using APV Cabinet Drier), milled, sieved to produce soybean-hull powder. The preliminary investigation showed the 85:15 ratio of the millet: egg composite powder to be the best using sensory evaluation and was therefore used as the base for formulation to which soybean-hull was added. The sensory (colour, aroma, mouth feel and taste), chemical (moisture, fat, ash, crude protein and carbohydrate), energy value and microbial qualities were determined.The average mean scores for colour, aroma, mouth feel and taste increased from 5.04-7.68, 4.16-5.52, 4.32-7.48 and 4.96-7.6 with increase in the added soybean-hull powder from 0-10\% and thereafter decreased. The moisture, protein, fat, carbohydrate and energy content decreased from 13.23$10.44,15.63-12.32,10.57-6.31 \%$ and $386.99-376.15 \mathrm{cal} / 100 \mathrm{~g}$, respectively, but the ash (mineral) and carbohydrate increased from 3.36-6.02 and 57.11-64.93\% with increase in the added soybean-hull powder $(0-25 \%)$. The work has shown that the combination of millet-eggsoybean/hull powder at 75:1510 with corresponding increase of protein, fat, and ash content of $19.44,7.1$ and $171 \%$, respectively, has proven to be the preferred product. This has shown a great improvement in the protein, ash and fat content of the accept product.
\end{abstract} \section{INTRODUCTION}

Keywords: Production, Evaluation, Millet-Egg-Soybean coat, Composite Flour, Weaning, Food.

In many West African countries, exclusive breastfeeding is usually adequate up to three to four months of age, but after this period it may become increasingly inadequate to support the nutritional demands of the growing infant. Thus, in a weaning process there is always the need to introduce soft, easily swallowed foods to supplement the infant's feeding early in life.

The weaning process may be gradual, lasting for months until the infant is finally introduced to the family diet. On the other hand, in abrupt weaning, the infant is introduced straight into the family menu. This latter option creates a problem, as the child may not be able to eat enough of the adult diet to meet his or her nutritional needs.

According to the available literature, West African mothers usually breastfeed for 12 months. Many urban poor and rural women breastfeed for up to 18 to 24 months (Kazimi and Kazimi 1979). These reports indicate that there is early supplementation with solid foods or early weaning. Although the majority of women start weaning their infants at the age of three to four months, a few begin within the first two months of life. The first solid food and the most popular weaning food is a thin cereal gruel that is called by different names depending on the type of cereal or the West African country. 
In Nigeria the usual first weaning food is called pap, akamu, ogi, or koko and is made from maize (Zea mays), millet (Pennisetum americanum), or guinea corn (Sorghum spp.)(King and Ashworth 1987; Longhurst 1984; Cherian 1981). In Anambra State most mothers introduce the thin gruel at three to six months of age (King and Ashworh 1987). The baby is fed on demand with a spoon or a cup, although in certain parts of the country, a few mothers use the traditional forced hand-feeding method (Osuhor 1980).

After the successful introduction of cereal gruel, other staple foods in the family menu are given to the child. These foods include yam (Dioscorea spp.), rice (Oryza sativa), gari (fermented cassava grits), and cocoyam (Xanthosoma sagittifolium), which may be eaten with sauce or soup (Morley et al., 1969; Naismith 1973). These foods are usually mashed, thinned, or pre-chewed. As soon as a child can chew, he or she is given pieces of food from the family pot. Some authors observed that in certain communities the low-income families do not make a special effort to prepare weaning foods for the infants, who are fed modified or unmodified food from the family pot (Okeke and Okafor 1989; Arinze 1984).

In Nigeria example of popular weaning food is ogi which could be made from maize, millet or sorghum depending on the mostly available in the community. Investigations showed these weaning foods to provide mostly calories but are grossly in adequate in proteins (Fashakin and Ogunsoola 1982). In addition, these foods should be able to supply vitamin $A$ and $C$ and Iron which mother's milk may not adequately supply (Okaka et al., 2002).

Many researchers have worked extensively on cereal-legume combinations in Nigeria. For example, formulated nut-ogi (a mixture of corn gruel and peanut), formulated soya-ogi (corn gruel plus soya bean), and the Collaborative Research Support Programme (CRSP) Cowpea Linkage Project at the University of Nigeria, Nsukka, formulated cerebabe (corn plus cowpea). Other useful combinations include ogi and melon protein (corn gruel plus melon seed) and cowpea-ogi (Fashakin and Ogunsoola, 1982; Akinrele and Edwards,1971; Plahar and Hoyle, 1991).

Some of these combinations have been adopted by the food-processing industries and are available in the Nigerian market. However, Fashakin et al., (1989) observed that no single protein from the above sources was adequate to promote growth or enhance nitrogen retention as well as a milk-based diet. To this end, a mixture of cowpea, melon, soya bean, and ogi was found to be superior to any single protein source in protein efficiency ratio, net protein retention, biological value, and net protein utilization ( Fashakin et al., 1989).

Traditional weaning foods in West Africa are known to be of low nutritive value (Akinrele and Bassir 1967; Guiro et al., 1987) and are characterized by low protein, low energy density, and high bulk. Maize pap or koko has been implicated in the aetiology of protein-energy malnutrition in children during the weaning period (Nasmith 1973). Cereal-based diets have lower nutritional value than animal-based ones.

The problems inherent in the traditional West African weaning foods and feeding practices predispose the infant to malnutrition, growth retardation, infection, and high mortality.

Several strategies may be used to improve the nutritive value of weaning foods. The traditional West African weaning foods could be improved by combining locally available foods that complement each other in such a way that the new pattern of amino acids created by this combination is similar to that recommended for infants (Uwaegbute and Nnanyelugo,1989). Cereals are deficient in lysine but have sufficient sulphur-containing amino acids that are limiting in legumes. Therefore, the combinations of cereals and legumes have been observed to produce amino acid patterns that adequately promote growth (Uwaegbute and Nnanyelugo, 1989).

Improving the qualities of these traditional weaning foods, therefore, is important to supply more available protein (Murano, 2003) and also some micronutrients such as iron, phosphorous and calcium which are needful for children growth.. Problems of nutrition during the weaning period are complex and sometimes complicated by many environmental factors. For example, early childhood infection, poverty of parents and ignorance among the population are some of the factors that affect the types of local weaning foods depend on the resources within the locality under consideration. The first consideration requires that the basic raw materials needed for the formulation be readily available. It is also essential that the knowledge and technical know-how for formulating the foods in proportions that would meet with daily requirements of the children be also available (FAO, 1974; Desrosier, 1977). 
Several strategies may be used to improve the nutritive value of weaning foods. The traditional West African weaning foods could be improved by combining locally available foods that complement each other in such a way that the new pattern of amino acids created by this combination is similar to that recommended for infants. Cereals are deficient in lysine but have sufficient sulphur-containing amino acids that are limiting in legumes. Therefore, the combination of cereals and legumes has been found to produce amino acid patterns that adequately promote growth.

The aim of the work is to improve the nutrient content of the local millet based weaning food by adding locally available raw materials.

\section{MATERIAL AND METHOD}

Millet (Eleusine coracana), egg and soyabeans used for the work were purchased in Gwallameji market Bauchi Nigeria.

Production of Materials: Millet (Eleusine caracane) was cleansed, washed, steeped (at room temperature for 24 hours), washed, wet milled, sieved (muslin cloth), sediment, decanted, pressed, dried, pulverized, sieved to produce millet flour. Egg (whole) were carefully broken, whisked, spray dried (Niro-Atomizer spray drier at drying/ product (of $150 / 75^{\circ} \mathrm{C}$ ) combination temperature to produce egg powder. Soybeans were sorted, cleansed, washed, and soaked (room temperature for $12 \mathrm{hrs}$ ), dehulled (manually), coat/hull dried (at $60^{\circ} \mathrm{C}$ for 3hrs using APV Cabinet Drier), milled, sieved to produce soybean coat powder.

Preliminary Investigation: The preliminary investigation carried out in order to produce qualitative weaning food involved substituting of the egg powder (0-20\%) into millet flour to produce weaning food and using sensory evaluation to determine the optimum acceptable level.

\section{METHODS}

Extrusion Process : Weighed dry materials (millet, soybean/egg powder) were properly mixed in Kenwood mixer, vegetable oil and water added, mixed, flattened by passing through the left side of the Cheff extruder. The flat paste is forced through the die in the right side of the extruder to produce the long strands of noodles, cut into desired length which are separated and allowed to dry under the room temperature.
The chemical analysis carried out includes: Moisture, fat, total ash, crude protein, carbohydrate and energy value determination (AOAC, 1984; FAO, 1986; Pearson, 1976). The energy values were calculated using the Atwater factors per gram of protein, fat and carbohydrate as 4,9 , and 4 Calories respectively (Eneche, 1999).

The microbial (bacterial and mold/yeast) analysis was carried out using the pour plate method (Jideani and Jideani 2006). The sample was analyzed for one week after storing under normal room temperature of $37^{\circ} \mathrm{C}$. The sensory evaluation of the samples was carried out for consumer acceptance and preference using 20 judges (students from Department of Food Science and Technology and students from Department of Mechanical Engineering of Federal Polytechnic, Bauchi), randomly selected using a Nine(9) point Hedonic scale (1 and 9 representing "extremely dislike" and "extremely like", respectively). The mean scores were differentiated using Analysis of Variance Methods. The qualities assessed include colour, texture, taste, flavour and general acceptance. Coded samples (steamed noodles) of the same size and temperature $\left(29^{\circ} \mathrm{C}\right)$ were served on a white plate of the same size to judges in each panel cupboard under the florescent light. Only one sensory attribute was tasted at one sitting. The data collected was analyzed statistically using ANOVA (Ihekoronye and Ngoddy 1985)

\section{RESULT AND DISCUSSION}

Preliminary Observation: The sensory evaluation result of egg-millet composite weaning food is summarized in Table 1. The average mean scores for the color, aroma, mouth feel and taste increased from 6.36-7.80, 5.76-6.56, 6.20-7.8 and 6.21-7.50, respectively with increase in the added powdered whole egg from $0-15 \%$ and there after decreased. The effect was significant at above $15 \%$ of added powder egg. Based on this evaluation result, eggmillet composite $(15: 85)$ was selected to form the base flour for production of the weaning food.

Effect of added soybean hull powder on the sensory quality of the egg-soybean hull-millet composite weaning food: The sensory evaluation result of the effect of added soybean coat powder on the egg-soybean hull-millet composite weaning food is summarized in Table 2. The average mean scores for colour, aroma, mouth feel and taste increased from 5.04-7.68, 4.16-5.52, 4.32-7.48 and 4.96-7.36 with increase in the added soybean coat powder from $0-10 \%$ and thereafter decreased. 
Effect of added soybean hull powder on the Chemical quality of the egg-soybean hull-millet composite weaning food: The added soybean hull powder generally affected the chemical composition of the product. The moisture, protein, fat, carbohydrate and energy content decreased from 13.23-10.44, 15.63-12.32, 10.57-6.31\% and 386.99$376.15 \mathrm{cal} / 100 \mathrm{~g}$, respectively, but the ash (mineral) and carbohydrate increased from 3.36-6.02 and $57.11-64.93 \%$ with increase in the added soybean coat powder $(0-25 \%)$. The decrease observed could be due to poor level of those respective nutrients in the added soybean coat and egg powder. The increase in the percentage of the ash (mineral) and carbohydrate contents could be due to the added soybean coat which has been noted to be very rich in mineral content particularly iron, phosphorus, sodium and potassium (Ewere, 1998; Iwe, 2002). Research has shown that egg powder contains about $49 \%$ protein, $43 \%$ fat and a useful source of riboflavin, vitamin A, iron and phosphorus. (Okaka, 2002; Okaka and Okaka, 2001; Ndukwe, 2006).

The addition of egg and soybean hull powder to millet flour could be a local and popular weaning food (at combination ratio of $75: 15: 10)$ as it will improved the protein, fat and ash (mineral) content by 19.44, 7.1 and $171 \%$, respectively. The increase in the protein level could help to prevent some of nutrient deficiency problems like kwashiorkor, marasmus and phenylketonuria which is prevalent in the developing Table 1: Average means score for sensory Evaluation of millet-egg Weaning Product

\begin{tabular}{|c|c|c|c|c|c|c|}
\hline \multicolumn{2}{|c|}{ Material } & \multirow[t]{2}{*}{ Colour } & \multirow[t]{2}{*}{ Aroma } & \multirow[t]{2}{*}{ Mouth feel } & \multirow[t]{2}{*}{ Taste } & \multirow{2}{*}{$\begin{array}{c}\text { General } \\
\text { acceptability }\end{array}$} \\
\hline Millet & Egg & & & & & \\
\hline 100 & 0 & $6.36 \mathrm{bc}$ & $5.76 a$ & $6.20 b$ & $6.21 b$ & $5.8 a$ \\
\hline 95 & 5 & $6.76 a b$ & $5.52 a$ & $6.28 b$ & $6.25 b$ & $6.04 a$ \\
\hline 90 & 10 & $7.44 a$ & $5.96 a$ & $6.48 b$ & $6.38 b$ & $6.56 a$ \\
\hline 85 & 15 & $7.80 a$ & $6.56 a$ & $7.8 \mathrm{a}$ & $7.5 a$ & $6.6 a$ \\
\hline 80 & 20 & $6.64 b$ & $6.24 a$ & $6.6 b$ & $5.20 b$ & $5.7 \mathrm{~b}$ \\
\hline 75 & 25 & $5.56 c$ & $5.80 \mathrm{a}$ & $5.64 b$ & $5.15 b$ & $5.52 b$ \\
\hline
\end{tabular}

${ }^{\star \star}$ Average mean scores with the same letter(s) are not significantly different, $p=0.05$

Table 2: Average Means Scores of Sensory Evaluation of millet-egg-soybean coat Weaning Food

\begin{tabular}{|c|c|c|c|c|c|c|}
\hline $\begin{array}{l}\text { Composite } \\
\text { flour }\end{array}$ & Soya bean-hull & Colour & Aroma & Mouth feel & Taste & $\begin{array}{l}\text { General } \\
\text { acceptability }\end{array}$ \\
\hline 100 & 0 & $5.04 \mathrm{~b}$ & $4.16 \mathrm{~b}$ & $4.32 \mathrm{~b}$ & $4.96 \mathrm{bc}$ & $4.96 \mathrm{~b}$ \\
95 & 5 & $5.4 \mathrm{~b}$ & $4.56 \mathrm{a}$ & $4.44 \mathrm{~b}$ & $4.76 \mathrm{bc}$ & $5.04 \mathrm{~b}$ \\
90 & 10 & $7.68 \mathrm{a}$ & $5.52 \mathrm{a}$ & $7.48 \mathrm{a}$ & $7.36 \mathrm{a}$ & $7.72 \mathrm{a}$ \\
85 & 15 & $5.16 \mathrm{~b}$ & $4.96 \mathrm{a}$ & $4.56 \mathrm{~b}$ & $6.56 \mathrm{a}$ & $5.84 \mathrm{~b}$ \\
80 & 20 & $4.76 \mathrm{~b}$ & $4.64 \mathrm{a}$ & $4.36 \mathrm{~b}$ & $4.2 \mathrm{bc}$ & $4.80 \mathrm{c}$ \\
75 & 25 & $5.08 \mathrm{~b}$ & $4.32 \mathrm{~b}$ & $3.88 \mathrm{~b}$ & $4.12 \mathrm{bc}$ & $4.32 \mathrm{c}$ \\
\hline
\end{tabular}

${ }^{\star}$ Composite flour $=85 \%$ millet and $15 \%$ egg powder

** Average mean scores with the same letter(s) are not significantly different, $p=0.05$ countries (Okaka et al 2002). The increase in the mineral content could help to prevent bone malformation as commonly observed in the children in developing countries like Nigeria.

Effect of added soybean-Hull powder on the microbial quality of the egg-soybean hull-millet composite weaning food: The microbial observations made on the products under storage are summarized in Table 4 and 5 . The bacteria count decreased from $3.0 \times 10^{4}$ to $1.4 \times 10^{4}$ and $4.0 \times 10^{4}$ to $2.0 \times 10^{4} \mathrm{cfu} / 100 \mathrm{~g}$ for the third and seventh day of storage, respectively with increase in the percentage of added soybean hull powder. The result also showed increase in the number of bacteria count with ncrease in the number of days of storage. The aerobic count though not detectable on the first day, 政 day with increase in the percentage of added (be decrease in the number of cue fungi/mould) could be added soybean coat powder as shown in Table 3. The total microbial load of the products is lower than the acceptable level $\left(1.0 \times 10^{5} \mathrm{cfu}\right)$ for weaning foods (Westhoff and Frazier, 1991; FAO, 1974; James, 1992), hence the safety of food is guaranteed if packed hygienically. fat. Carbohydrate) and moisture content with the 
Am. J. Food. Nutr, 2011, 1(1): 7-13

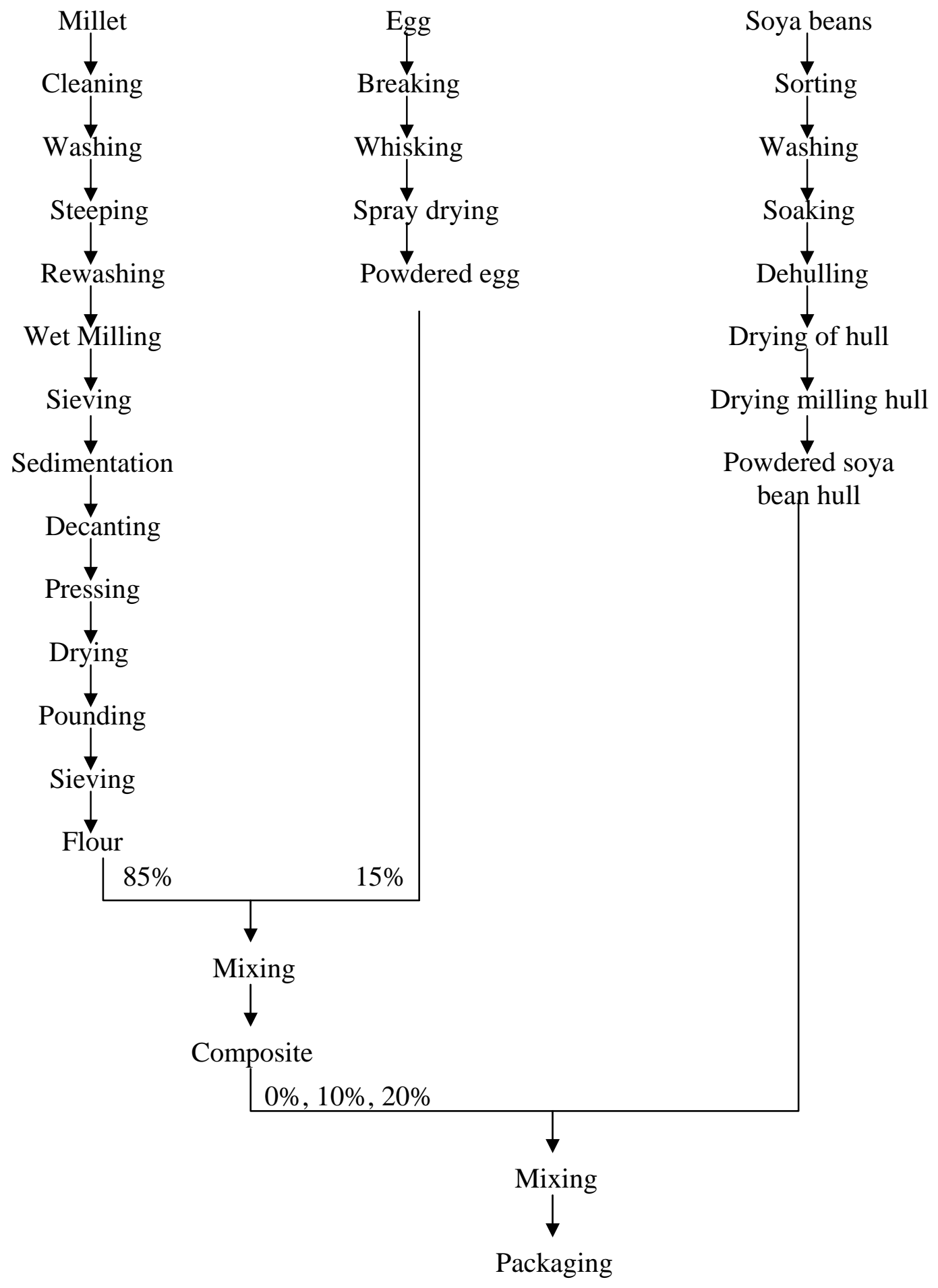


Table 3: Proximate Composition of Millet-Egg-Soybean-hull Weaning Product

\begin{tabular}{|c|c|c|c|c|c|c|c|}
\hline $\begin{array}{c}\text { *Composite } \\
\text { Flour }\end{array}$ & $\begin{array}{c}\text { Soyabean } \\
\text { hull }\end{array}$ & Moisture \% & Protein \% & Fat \% & Ash \% & $\begin{array}{c}\text { Cho \% } \\
\text { Energy } \\
\text { Value }\end{array}$ \\
\hline 100 & 0 & 13.23 & 15.63 & 10.67 & 3.36 & 57.11 & 386.99 \\
95 & 5 & 12.88 & 15.095 & 9.8 & 4.59 & 57.63 & 379.12 \\
90 & 10 & 12.53 & 14.56 & 8.93 & 5.83 & 58.16 & 371.25 \\
85 & 15 & 11.89 & 13.71 & 7.9 & 5.91 & 60.59 & 368.3 \\
80 & 20 & 11.26 & 12.86 & 6.87 & 5.99 & 63.02 & 365.35 \\
75 & 25 & 10.44 & 12.30 & 6.31 & 6.02 & 64.93 & 376.15 \\
\hline
\end{tabular}

${ }^{\star}$ Composite flour $=85 \%$ millet and 15\% egg powder

Table 4: Total Bacterial Plate Count (cfu/g) in 7 days

\begin{tabular}{|l|c|c|c|c|}
\hline ME & SC & Day One & Day Three & Day Seven \\
\hline 100 & 0 & $1.0 \times 10^{4}$ & $3.0 \times 10^{4}$ & $4.0 \times 10^{4}$ \\
95 & 5 & $1.0 \times 10^{4}$ & $3.1 \times 10^{4}$ & $4.4 \times 10^{4}$ \\
90 & 10 & $1.0 \times 10^{4}$ & $2.1 \times 10^{4}$ & $3.5 \times 10^{4}$ \\
85 & 15 & $1.0 \times 10^{4}$ & $2.1 \times 10^{4}$ & $3.0 \times 10^{4}$ \\
80 & 20 & $1.0 \times 10^{4}$ & $2.0 \times 10^{4}$ & $3.0 \times 10^{4}$ \\
75 & 25 & $1.0 \times 10^{4}$ & $1.4 \times 10^{4}$ & $2.0 \times 10^{4}$ \\
\hline
\end{tabular}

ME-Composite flour $=85 \%$ millet and 15\% egg powder

SC-Soybean-hull powder

Table 5: Total Aerobic Count (Mould and Yeast) cfu/g in 7 days

\begin{tabular}{|c|c|c|c|c|}
\hline ME & SC & $\begin{array}{c}\text { Total } \\
\text { Day One }\end{array}$ & $\begin{array}{l}\text { Aerobic Count } \\
\text { Day Three }\end{array}$ & (cfu/00g) \\
\hline 100 & 0 & NG & $2.0 \times 10^{4}$ & $9.0 \times 10^{4}$ \\
\hline 95 & 5 & NG & $2.0 \times 10^{4}$ & $8.4 \times 10^{4}$ \\
\hline 90 & 10 & NG & $1.3 \times 10^{4}$ & $4.0 \times 10^{4}$ \\
\hline 85 & 15 & NG & $1.0 \times 10^{4}$ & $4.0 \times 10^{4}$ \\
\hline 80 & 20 & NG & $3.0 \times 10^{4}$ & $4.0 \times 10^{4}$ \\
\hline 85 & 25 & NG & $2.0 \times 10^{4}$ & $3.0 \times 10^{4}$ \\
\hline
\end{tabular}

\section{CONCLUSION}

The study has demonstrated the use of millet- eggsoybean hull composite flour in the production of weaning food. The work has shown that the combination of millet,-egg-soybean coat flour at 75 : 15:10 has proven to be the preferred product. The nutrient content of the acceptable product has been greatly improved (protein, fat and ash content to $19.44,7.1$ and $171 \%$, respectively). The microbial quality of the products falls within the acceptable standard, hence guarantying the safety of the consumer. The use of composite flour for weaning of children would help to improve the nutritional value at presumably cheaper cost since all the raw materials are locally available and does not require special skill for the preparation.

\section{REFERENCES}

Akinrele IA, Bassir O. (1967) Nutritional value of "ogi," a Nigerian infant food. J Trop Med Hyg 70: 279-81.

Akinrele I.A and Edwards C.A.(1971) An assessment of the nutritional value of maize-soy mixture "soy-ogi" as a weaning food in Nigeria. Br J Nutr ; 26: 172-85.

AOAC (1984). Official methods of Analysis, $13^{\text {th }}$ ed. Association of Analytical Chemist Washington D. C. pp. $24-26$.

Armar M.A(1989). Maternal energy status, lactational capacity and infant growth in rural Ghana: a study of the interaction of cultural and biological. Doctoral thesis, University of London.

Arinze P.C(1984). The pattern of weaning in different socioeconomic groups in Nsukka. Bachelor of Science degree thesis, University of Nigeria, Nsukka. 
Cherian A(1981). Attitudes and practices of infant feeding in Zaria. Ecol Food Nutr 11:75-80.

Desosier, W. A. (1977). Element of food technology Aut publishing company Inc. West Port Connectueut pp. 68-93.

Enwere, N. J. (1998). Foods of plant origin, processing and utilization with Recipes and Technology profiles $1^{\text {st }}$ ed. Afro-orbis publications limited. Pp. 131-133.

Eneche E.H(1999) Biscuit making Potential of Millet/pigeon Pea flour Blends. Plant Foods for Human Nutrition 54:21-27.

Fashakin JB and Ogunsoola F(1982). The utilization of Local foods in fermentation of weaning foods Trops Paediatr (Lon) 28:93-6

Fashakin JB, Awoyefa MB and Furst P(1986). The application of protein concentrates from locally available legumes in development of weaning foods. $J$ Nutr Sci Ernahrungswisse 25: 220-7.

FAO of the United Nations (1974). Handbook on Nutrition and health, $2^{\text {nd }}$ ed. Food Agriculture Organization Rome. P. 66.

Guiro A.T, Sail M.G, Kane O, Ndiaye A.M, Diarra D and(1987) Sy M.T. Protein-calorie malnutrition in Senegalese children. Effects of rehabilitation with a pearl millet weaning food. Nutr Rep Int ; 36: 1071-9.

M.O (2002) Science and Technology of soybean. ROJOINT Coomunication Services Ltd Enugu Nigeria.

James, M. J. (1992). Modern Food Microbiology. $4^{\text {th }}$ ed. Van Nostrand keinholds New York pp. 239 - 436.

Kazimi J, Kazimi HR. Infant feeding practices of the Igbo. Ecol Food Nutr 1979; 8: 111-6.

King J, Ashworth A. Changes in infant feeding practices in Nigeria: an historical review. Occasional Paper No. 9. London: Centre for Human Nutrition, London School of Hygiene and Tropical Medicine, 1987

Kent, N. L. (1984). Technology of cereal $2^{\text {nd }}$ ed. Pergaman press LTd, London pp.201-208.

Longhurst $\mathrm{R}$. The energy trap. Work, nutrition and childhood malnutrition in Northern Nigeria. International Monograph Series 13. Ithaca, NY, USA: Cornell University, 1984.

Morley D, Bicknell H, Woodland M(1968). Factors influencing the growth and nutritional status of infants and young children in a Nigerian village. Trans $R$ Soc Trop Med Hyg 62: 164-95.
Murano, S. P. (2003).Understanding Food Science and Technology. Peter Marshall publications U.S.A. pp. 1115.

Naismith DJ. Kwashiorkor in Western Nigeria: a study of traditional weaning foods with particular respect to energy and linoleic acid. Br J Nutr 1973: 80: 567-76.

Ndukwe, O. (2006). Production of special enriched Ogi powder using sorghum, soyabean, ginger, cloves and chilki pepper. Unpublished data. Department of Food Science and Technology, Federal Polytechnic Bauchi.

Okaka, J. C., Akokundu, N. Y and Antoneth W. C. (2002). Human nutrition on integrated approach $2^{\text {nd }}$ ed. Ocjanco Academic publishers, 4 Oboro str. Enugu pp. 111-115

Okaka, J. C. and Okaka, A. M. C. (2001). Foods: Composition spoilage, shelf life extension. Serves No. 1 Ocjanco Academics publishers Enugu pp. 252 253.

Okeke EC, Okafor US. Current breast-feeding and weaning practices in Anambra State. Nigerian J Nutr Sci 1989: 10: 21-3.

Osuhor PC. Weaning practices amongst the Hausas. J Hum Nutr 1980; 34: 273-80.

Plahar WA, Hoyle NT. Estimated protein quality of weaning blends from local cereals and legumes. In: Sefa-Dedeh $\mathrm{S}$, ed. The development of high protein-energy foods from grain legumes. Proceedings of the AAU/UNU international seminar held in Accra, Ghana, 5-7 February 1991. Accra: University of Ghana, 1991: 7587.

Pearson, D. C. (1976). The Chemical Analysis of food $7^{\text {th }}$ ed. Churchill Livingstone edinbing London. Pp. 153 157.

Uwaegbute A.C and Nnanyelugo D.O(1989). towards improving the nutritional value of traditional weaning foods. In: Fashakin JB, ed. Proceedings of the workshop on present knowledge on weaning foods in Nigeria, held in Lagos, 29-30 August 1989. OshodiLagos: Federal Institute for Industrial Research, 63-85.

Westhoff, D. and Frazier, W. C. (1991). Food Microbiology $3^{\text {rd }}$ ed. McGraw publishing company Ltd. New York. Pp. 84-92.

http://www.Illi.org/IIlederweb/LV/LVDecooJanap112html. 7 - $03-09$

http://www.IIli

wwwtropej.oxfordjounals.org/content/vol28/issue/pdfextract/93.jpeg7-03 - 09. 